Vol. 18 (2009): 234-256.

\title{
Formic acid treated whole crop barley and wheat silages in dairy cow diets: effects of crop maturity, proportion in the diet, and level and type of concentrate supplementation
}

\author{
Seija Jaakkola ${ }^{1}$, Eeva Saarisalo ${ }^{2,3}$ and Terttu Heikkilä ${ }^{2}$ \\ ${ }^{1}$ Department of Animal Science, PO Box 28, FI-00014 University of Helsinki, Finland \\ e-mail:seija.jaakkola@helsinki.fi \\ ${ }^{2}$ MTT Agrifood Research Finland, Animal Production Research, FI-31600 Jokioinen, Finland \\ ${ }^{3}$ Currently: Ministry of Agriculture and Forestry, Department of Food and Health, PO Box 30,
}

FI-00023 Valtioneuvosto, Finland

\begin{abstract}
Three trials in dairy cows were carried out to study the effects of replacing grass silage (GS) with wholecrop silage (WCS) made of barley (BS) or wheat (WS) harvested at dough stage with a dry matter (DM) concentration of 300-450 $\mathrm{g} \mathrm{kg}^{-1}$. All silages were ensiled using a formic acid based additive $5 \mathrm{lt}^{-1}$. Milk production responses to energy and protein supplementation of diets were studied. In Exp. 1, BS replaced GS at the rates of $0,200,400$ or $600 \mathrm{~g} \mathrm{~kg}^{-1}$ forage DM. Also $10 \mathrm{~kg}$ of concentrate containing 0 or $2 \mathrm{~kg}$ of rape seed meal was fed. In Exp. 2, barley was harvested at three times (BS1, BS2, BS3) at one week intervals. Barley silages were fed as a mixture with GS (40:60) and in addition BS2 and GS alone. Silages were supplemented with a cereal based farm-made concentrate (FC) or a commercial compound having a lower concentration of starch than FC. In Exp. 3, barley and wheat were harvested at two week intervals, fed as a mixture with GS (40:60) and supplemented with low or high amount of concentrate.

The fermentation quality of whole crop silages was good. Weather conditions and maturity affected the proportion of ear in the crop and subsequently the ratio of non-structural carbohydrates to NDF in the silage. The inclusion of WCS depressed diet OM digestibility depending on the digestibility of GS and the proportion of WCS in the diet. However, mixing GS and WCS did not depress intake. Subsequently the use of mixtures maintained or even increased milk yield as compared with GS diet in Exp. 2 and 3. In Exp. 1, higher proportions $\left(400,600 \mathrm{~g} \mathrm{~kg}^{-1}\right)$ of BS decreased milk yield. Minor effects of growth stage on milk production were observed with barley whereas delaying wheat harvest increased milk yield. Different types and levels of concentrate induced mainly similar intake and milk yield responses with diets based on GS alone or on mixtures of GS and WCS. The synergistic effect of mixing GS and WCS was more positive in experiments where the protein concentration of concentrate was high $\left(200 \mathrm{~g} \mathrm{~kg}^{-1} \mathrm{DM}\right)$.
\end{abstract}

Key-words: whole-crop, barley, wheat, grass, silage, dairy cow, milk 


\section{AGRICULTURAL AND FOOD SCIENCE}

Vol. 18 (2009): 234-256.

\section{Introduction}

Agronomic and economic information indicates that inclusion of harvest of the whole crop (WC) cereals in the farming system has many advantages (Stark and Wilkinson 1995). Most of the literature on the use of whole crop silage (WCS) in dairy cow feeding is for wheat silage. Being suitable for the northern climate, barley and oats have been the dominant small grain cereals in Finland. Due to the lower fibre concentration and better feeding value (Kristensen 1992), barley is regarded as a better alternative than oats for high yielding dairy cows. Since harvesting as WCS does not require full maturity of cereals, higher yielding wheat varieties could be an option in areas where barley or oats has been used.

The variation in the composition and feeding value of cereal crops is mainly associated with the differences in the proportion of grain and straw (Kristensen 1992, Südekum and Arndt 1998). Much of the variation is caused by variety and timing of harvest, in addition to environmental factors like location, weather and growth conditions. However, the effects of straw proportion are not clear since increased grain proportion, by advancing maturity or by elevated cutting heights does not necessarily affect intake of WC silage or animal performance (e.g. Sutton et al. 2002, Sinclair et al. 2003).

There is ample evidence that feeding a mixture of grass silage and fermented or alkaline WC cereals in dairy cow feeding may increase silage intake (e.g. Leaver and Hill 1995, Phipps et al. 1995, Sutton et al. 1997). However, some negative effects like lack of positive milk yield responses, low energy value, low starch digestibility and potential pollution caused by nitrogen have been observed when using urea-treated WC wheat silage (Sutton et al. 2002). Successful preservation with alkalis, principally urea, requires a dry matter (DM) concentration of approximately $500 \mathrm{~g} \mathrm{~kg}^{-1}$. When immature low DM cereals are ensiled with $\mathrm{NaOH}$ or urea, butyric acid fermentation may occur (Deschard et al. 1987, Tetlow 1992). In Finland, ensiling of untreated and urea-treated WC silage resulted in clostridial fermentation (Alaspää 1986) which, besides reducing the nutritive value of silage, poses a high risk for the quality of dairy products. In Nordic climatic conditions, the DM concentration of whole crop cereals is often low, even at late maturity of grain. Thus, ensiling of cereal crops should preferably be based on low $\mathrm{pH}$ generated by fermentation and/or additives, and the harvest should be done at the dough stage with a DM concentration of 300-400 $\mathrm{g} \mathrm{kg}^{-1}$ (Vanhatalo et al. 1999). In the experiment by Vanhatalo et al. (1999) formic acid proved to be a potential preservative for whole crop cereals at dough stage by restricting in-silo fermentation and protein breakdown as compared to untreated silage. The early harvested small grain cereal crops have been ensiled successfully (Edwards et al. 1968, Bergen et al. 1991, Südekum and Arndt 1998) and fermented whole crop silages do not necessarily present problems with aerobic stability (Sutton et al. 2002) as observed in earlier works (Tetlow 1992).

No previous studies were conducted on the use of WC silage in dairy cow feeding in Finland. Thus there was a need to identify the correct stage of harvest and appropriate concentrate supplementation of formic acid treated barley silage. It was essential to understand the relationship between growth conditions and cereal crop development, and subsequently, how it affects the ensiling characteristics and nutritive value of whole crop cereals. The present series of experiments were undertaken to evaluate the effects of inclusion of formic acid treated whole crop barley or wheat silages in a grass silage based diet on intake and milk production in dairy cows. The effects of advancing maturity of barley and wheat during dough stage, and the effects of protein supplementation, type of concentrate and concentrate level in dairy cow diet were studied.

\section{Material and methods}

\section{Harvest}

Spring-sown barley (Hordeum vulgare L. cv. Inari, two-rowed) was used in three experiments and 


\section{AGRICULTURAL AND FOOD SCIENCE}

Jaakkola, S. et al. Whole-crop silage for dairy cows

spring-sown wheat (Triticum aestivum L. cv. Mahti) in one experiment. Both were harvested on the farm of Jokioinen Estates in MTT Agrifood Research Finland, Jokioinen $\left(60^{\circ} 49^{\prime} \mathrm{N}, 23^{\circ} 28^{\prime} \mathrm{E}\right)$. In the first experiment (Exp. 1) barley was harvested on $14^{\text {th }}$ August 1996 at the early dough stage 27 days after the start of heading (Table 1). In the second experiment (Exp. 2), barley was harvested three times (BS1-BS3) at one week intervals (on $22^{\text {nd }}$ July, $29^{\text {th }}$ July and $4^{\text {th }}$ August 1999) starting from the early dough stage 14 days after heading. In the third experiment (Exp. 3), whole crop barley and wheat were harvested at the early and soft/hard dough stages. Barley was harvested 23 (BS1) and 36 (BS2) days (on $3^{\text {rd }}$ and $16^{\text {th }}$ August 2000), and wheat 30 (WS1) and 44 (WS2) days after the onset of heading (on $10^{\text {th }}$ and $24^{\text {th }}$ August 2000). The harvest dates were determined by a combination of crop DM concentration and colour and grain DM and texture. Growing season was exceptionally warm and dry during Exp. 2. The mean temperature in June and July was $13.6,17.5$ and $14.6{ }^{\circ} \mathrm{C}$, and precipitation 188, 79 and $165 \mathrm{~mm}$ in Exp. 1, 2 and 3 , respectively.

The whole crops were harvested direct-cut using a flail harvester (Taarup 1500, Kerteminde, Denmark; Exp. 1) or a double chop harvester (Tupla-Junkkari, Junkkari Oy, Finland; Exp. 2 and Exp. 3) at stubble height of about $10 \mathrm{~cm}$. Silages were treated with a formic acid based additive applied at the rate of $51 \mathrm{t}^{-1}$ (Exp. 1: AIV-10 containing formic acid 775, orthophosphoric acid 20 and ethylbenzoate $25 \mathrm{~g} \mathrm{~kg}^{-1}$, Kemira Chemicals Oyj; Exp. 2 and Exp. 3: AIV2000 containing formic acid 550, ammoniumformate 240 , propionic acid 50 , benzoic acid 10 and ethylbenzoate $10 \mathrm{~g} \mathrm{~kg}^{-1}$, Kemira Chemicals Oyj) and ensiled in bunker silos. Grass silage (GS) was harvested from a primary $\left(24^{\text {th }}\right.$ June Exp. 1 and $15^{\text {th }}-16^{\text {th }}$ June Exp. 3) or secondary growth $\left(27^{\text {th }}-29^{\text {th }}\right.$ September Exp. 2$)$ of mixed timothy (Phleum pratense L.) and meadow fescue (Festuca pratensis Huds.) swards. The herbage was mown using a mower conditioner, harvested with a precision-chop forage harvester after a 4-6 $\mathrm{h}$ wilting period, treated with the same additives and application rates as the whole crop silages, and ensiled in bunker (Exp. 1 and 2) or tower (Exp. 3) silos. The additives were applied using a pump applicator (Ylö HP-20, Ylöjärvi, Finland) attached to the forage harvester.

\section{Experimental design and diets}

Three feeding experiments were conducted using a cyclic change-over design (Davis and Hall 1969) with 16 (Exp. 1) or 20 (Exp. 2 and 3) cows. The duration of all the experiments was 84 days consisting of four 21-day experimental periods with an adaptation period from day 1 to 13 followed by a sampling period from day 14 to 21 . Finnish Ayrshire cows were selected from the dairy herd of Jokioinen Estate. The cows were housed in individual stalls and had free access to silage allowing 5 to $10 \%$ refusals. Silages were grass silage or whole crop silage alone or a combination mixed using a mixer wagon. Daily concentrates were offered as three equal meals at $5.30,12.30$ and $16.30 \mathrm{~h}$.

Exp. 1 was conducted with eight dietary treatments and with two replicate blocks of eight multiparous cows each. The cows were divided into blocks according to milk yield and feed intake, and allocated at random to the experimental treatments. At the beginning of the experiment, the cows had a mean (s.d.) live weight of $575 \mathrm{~kg}$ (47.5), a parity of 3.4 (1.55) and were 62 days (15.1) in lactation, producing $31.8 \mathrm{~kg}$ (2.93) milk per day. Dietary treatments in a $4 \times 2$ factorial arrangement consisted of four silage mixtures and two protein supplement rates (no supplement (-RSM) and rapeseed meal $(+\mathrm{RSM})$ ).

Grass silage (GS) was gradually replaced by barley silage (BS) in the diet at the rates of 0 (BS0), 200 (BS20), 400 (BS40) or 600 (BS60) $\mathrm{g} \mathrm{kg}^{-1}$ of silage DM. The basal concentrate mixture (Table 2) was formulated from barley $\left(384 \mathrm{~g} \mathrm{~kg}^{-1}\right)$ and oats $\left(384 \mathrm{~g} \mathrm{~kg}^{-1}\right)$ coarsely ground with a hammer mill, dry molassed sugar beet pulp $\left(192 \mathrm{~g} \mathrm{~kg}^{-1}\right)$ and mineral and vitamin supplement $\left(40 \mathrm{~g} \mathrm{~kg}^{-1}\right)(\mathrm{Ca}$ 160, P 64, Na 90, Mg $80 \mathrm{~g} \mathrm{~kg}^{-1}$, vitamin A 150 000, vitamin D $100000 \mathrm{IU} \mathrm{kg}^{-1}$, and vitamin E $500 \mathrm{mg}$ $\mathrm{kg}^{-1}$; Viher-Hertta-Minera, Suomen Rehu Ltd, Helsinki, Finland). In protein-supplemented diets 
Vol. 18 (2009): 234-256.

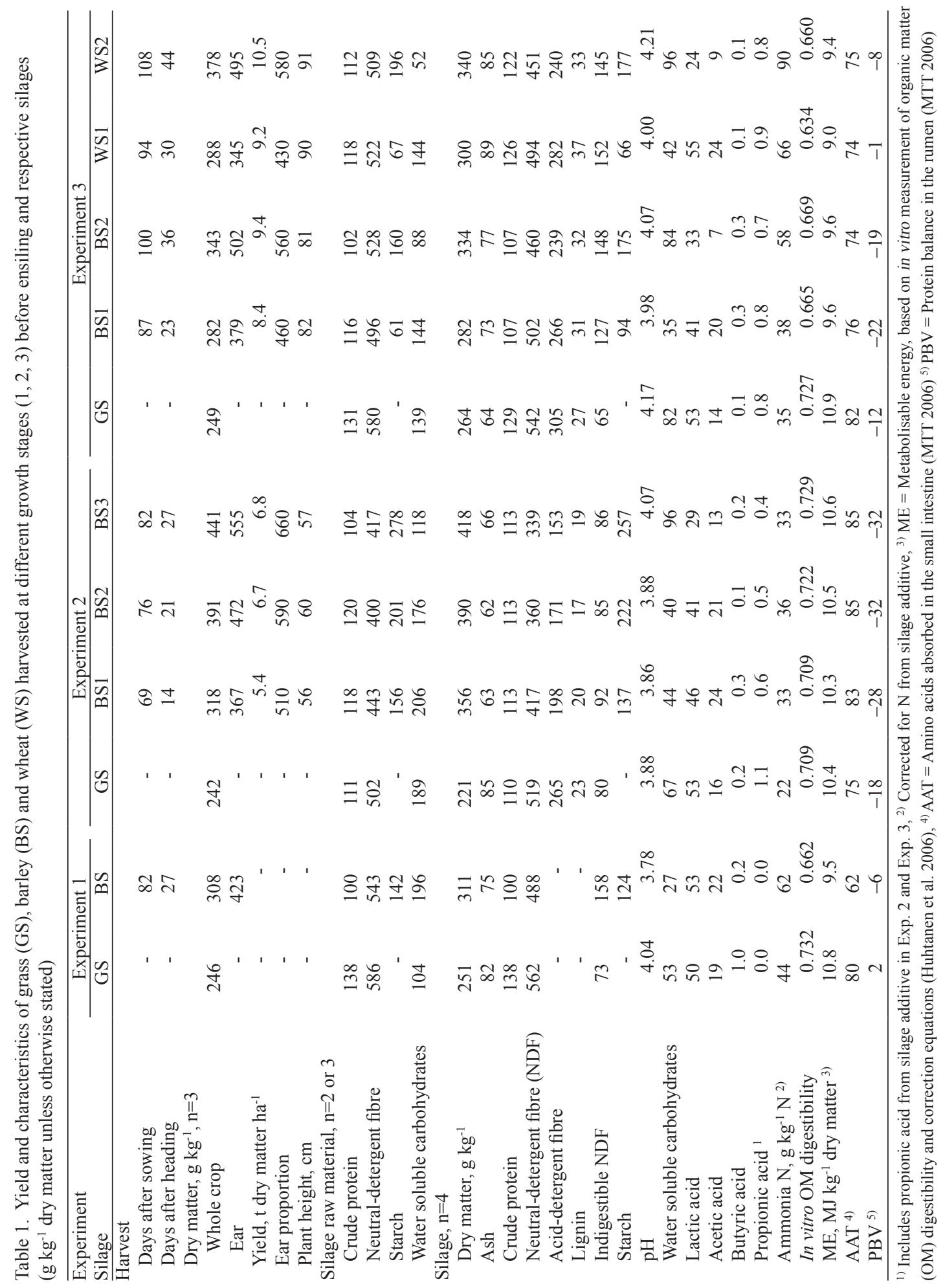




\section{AGRICULTURAL AND FOOD SCIENCE}

Jaakkola, S. et al. Whole-crop silage for dairy cows

solvent-extracted rapeseed meal (Raisio Feed Ltd, Raisio, Finland) replaced $2 \mathrm{~kg}$ of the basal mixture. Concentrate (110 or $164 \mathrm{~g}$ crude protein (CP) $\mathrm{kg}^{-1}$ $\mathrm{DM}$ ) was offered at a rate of $10 \mathrm{~kg}$ per day.

Exp. 2 was conducted with ten dietary treatments and with two replicate blocks (one for primiparous, one for multiparous) of 10 cows each. The cows were selected so that each block involved group of cows which was as homogenous as possible on the basis of milk yield and feed intake. Within the blocks the cows were allocated at random to the experimental treatments. The cows had a mean (s.d.) live weight of $580 \mathrm{~kg}$ (72.9), and were 75 days (29.2) in lactation, producing 30.6 $\mathrm{kg}(7.50)$ milk per day. Dietary treatments in a $5 \times 2$ factorial arrangement consisted of five silages and two types of concentrates.

Silage treatments were GS, BS2, GS+BS1, GS+BS2, GS+BS3. The proportion of whole crop silage was $400 \mathrm{~g} \mathrm{~kg}^{-1}$ silage DM. A farm made concentrate mixture (FC) and a commercial compound (CC) having equal crude protein $\left(197 \mathrm{~g} \mathrm{~kg}^{-1}\right.$ $\mathrm{DM})$ and $\mathrm{ME}$ (12.7 MJ ME kg-1 DM) concentrations were compared (Table 2). Concentrate was offered at $11.0 \mathrm{~kg}$ per day. The farm made mixture was formulated $\left(\mathrm{g} \mathrm{kg}^{-1}\right)$ from barley (470) and oats (250) coarsely ground with a hammer mill, rapeseed cake (Mildola, Helsinki, Finland) (250), mineral and vitamin supplement (18.2) (Ca 160, P 64, Na 90, Mg $80 \mathrm{~g} \mathrm{~kg}^{-1}$, A vitamin 150 000, D vitamin $100000 \mathrm{IU} \mathrm{kg}^{-1}$, and $\mathrm{E}$ vitamin $500 \mathrm{mg}$ $\mathrm{kg}^{-1}$; Viher-Hertta-Minera, Suomen Rehu Ltd, Helsinki, Finland), calcium carbonate (8.2) and sodi- um chloride (3.6). Pelleted CC (Raisio Feed Ltd, Raisio, Finland) consisted ( $\mathrm{g} \mathrm{kg}^{-1}$ ) of wheat (125), oats (125), barley (125), molassed sugar beet pulp (125), wheat middling (120), soybean meal (120), wheat molasses (60), rape seed meal (60), rape seed cake (60), vegetable oil (21), propylene glycol (10) and vitamin and trace element premix (49).

Exp. 3 was conducted with ten dietary treatments and with two replicate blocks (one for primiparous, one for multiparous) of 10 cows each. The cows were selected so that each block involved group of cows which was as homogenous as possible on the basis of milk yield and feed intake. Within the blocks the cows were allocated at random to the experimental treatments. The cows had a mean (s.d.) live weight of $556 \mathrm{~kg}$ (39.9), and were 57 days (17.7) in lactation, producing 33.6 $\mathrm{kg}(6.70)$ milk per day. Dietary treatments in a $5 \times 2$ factorial arrangement consisted of five silage mixtures and two amounts of concentrates. Silage treatments were as follows: GS, GS+BS1, GS+BS2, GS+WS1, and GS+WS2. The proportion of whole crop silage was $400 \mathrm{~g} \mathrm{~kg}^{-1}$ of silage DM. A pelleted commercial compound (Raisio Feed Ltd, Raisio, Finland) was offered at either 9 or $14 \mathrm{~kg}$ per day for the multiparous cows. The primiparous cows received proportionately 0.80 of concentrates (7.2 and $11.2 \mathrm{~kg}$ ) fed to multiparous cows. Concentrate consisted of oats $\left(154 \mathrm{~g} \mathrm{~kg}^{-1}\right)$, barley $\left(200 \mathrm{~g} \mathrm{~kg}^{-1}\right)$, molassed sugar beet pulp $\left(120 \mathrm{~g} \mathrm{~kg}^{-1}\right)$, wheat middling (120 $\left.\mathrm{g} \mathrm{kg}^{-1}\right)$, rape seed meal $\left(300 \mathrm{~g} \mathrm{~kg}^{-1}\right)$, wheat molasses $\left(70 \mathrm{~g} \mathrm{~kg}^{-1}\right)$ and vitamin and trace element premix $\left(36 \mathrm{~g} \mathrm{~kg}^{-1}\right)$ (Table 2).

Table 2. Mean chemical composition of concentrates $\left(\mathrm{g} \mathrm{kg}^{-1}\right.$ dry matter, unless otherwise stated) $(\mathrm{n}=2$ for each experiment).

\begin{tabular}{|c|c|c|c|c|c|}
\hline & \multicolumn{2}{|c|}{ Experiment 1} & \multicolumn{2}{|c|}{ Experiment 2} & \multirow[t]{2}{*}{ Experiment 3} \\
\hline & $-\mathrm{RSM}^{1)}$ & $+\mathrm{RSM}$ & $\mathrm{FC}^{2)}$ & $\mathrm{CC}^{3)}$ & \\
\hline Dry matter, $\mathrm{g} \mathrm{kg}^{-1}$ & 885 & 886 & 885 & 879 & 862 \\
\hline Ash & 82 & 78 & 67 & 66 & 71 \\
\hline Crude protein & 110 & 164 & 202 & 193 & 210 \\
\hline Ether extract & - & - & 58 & 63 & 48 \\
\hline Neutral-detergent fibre & 249 & 258 & 235 & 235 & 270 \\
\hline Starch & - & - & 353 & 249 & 204 \\
\hline Metabolisable energy, $\mathrm{MJ} \mathrm{kg}^{-1}$ dry matter & 12.2 & 12.0 & 12.6 & 12.7 & 11.9 \\
\hline Amino acids absorbed in the small intestine & 98 & 110 & 113 & 112 & 114 \\
\hline Protein balance in the rumen & -36 & 0 & 10 & 20 & 16 \\
\hline
\end{tabular}

${ }^{1)} \mathrm{RSM}=$ rape seed meal, ${ }^{2)} \mathrm{FC}=$ farm-made concentrate, ${ }^{3)} \mathrm{CC}=$ commercial compound 


\section{AGRICULTURAL AND FOOD SCIENCE}

Vol. 18 (2009): 234-256.

\section{Sampling and analyses}

Both barley and wheat fields were divided into three sub-areas. The yield of the whole crop was estimated before harvesting by taking plant samples from four replicates of $0.25 \mathrm{~m}^{2}$ on each sub-area. The height of the cereals was measured, the samples were cut at the height of $8 \mathrm{~cm}$, pooled over the sub-areas resulting in three samples, weighed and analysed for DM concentration separately for whole crop and ears. Samples of whole crop cereals and grass were collected from every load at the time of ensiling and immediately stored at $4{ }^{\circ} \mathrm{C}$. The samples were pooled over three loads resulting in two or three samples per treatment. Once ensiling was completed, samples were submitted for the determination of DM, total nitrogen $(\mathrm{N})$, neutral detergent fibre (NDF) and water soluble carbohydrates (WSC), and whole crop cereal samples also for starch determination. During the sampling period of the animal experiment, representative samples of silages were collected before mixing, and samples of silage mixtures and concentrates were collected daily. Concentrates were analysed for DM, ash, N, NDF, starch and acid insoluble ash (AIA). Silages were analysed for DM, ash, N, NDF, acid detergent fibre (ADF), lignin, starch, AIA, in vitro organic matter digestibility, indigestible NDF (iNDF), pH, lactic acid, VFA, WSC and ammonia N. Silage samples and DM concentration of concentrate were analysed separately for each period. For the determination of chemical composition, concentrate samples were pooled over two periods resulting in two separate determinations.

Feed intake and milk yield were recorded daily. Cows were milked twice daily at 6.30 and $15.30 \mathrm{~h}$. Milk samples were obtained from four consecutive milkings on day 18 to 20 and analysed by an infrared milk analyser (Milko-Scan 133B, Foss Electric, Hillerød, Denmark) for fat, protein and lactose. A separate milk sample from two consecutive milkings on day 20 was taken for urea determination. Cows were weighed on two consecutive days at the beginning of the experiment and on days 20 and 21 of each experimental period at $10.00 \mathrm{~h}$.
Whole tract apparent digestibility was estimated using AIA as an internal marker (van Keulen and Young 1977). During the last 5 days of each period spot faecal samples were collected at 06.30 and $15.30 \mathrm{~h}$ from 8,10 and 10 cows assigned to the blocks of multiparous cows in Exp. 1, 2 and 3 , respectively. At the end of each period, samples were pooled on an individual cow basis, thoroughly mixed, subsampled and stored at $-20{ }^{\circ} \mathrm{C}$.

Energy value for concentrates was calculated using published digestibility coefficients (MTT 2006) for each ingredient. Grass and whole crop silage ME values in the Table 1 are based on in vitro -measurement. Protein balance in the rumen (PBV) and amino acids absorbed in the small intestine (AAT) were calculated according to a modified Nordic AAT-PBV protein evaluation system adopted in Finland (MTT 2006). Forage AAT and PBV concentrations were calculated using the equations based on crude protein concentration and measured digestible organic matter $(\mathrm{OM})$ in DM (MTT 2006). Concentrate AAT and PBV concentrations were calculated using published values for individual concentrate ingredients (MTT 2006). Estimates of the efficiency of utilization of AAT for milk protein synthesis and milk production were calculated ignoring changes in live weight.

The metabolisable energy (ME) concentration of the diets was calculated based on predicting ME intake from digestible OM measured in cows assuming a ME concentration of $16 \mathrm{MJ} \mathrm{kg}^{-1}$ digestible OM (MAFF 1975). Calculations were conducted using AIA based digestibility measurements for individual cows within block 1 and mean treatment values for block 2 , since individual measurements of digestibility were not made for these animals. Milk energy concentration was estimated according to Sjaunja et al. (1990) and ME requirement for maintenance according to MAFF (1984). The efficiency of utilization of $\mathrm{ME}\left(\mathrm{k}_{1}\right)$ for milk production was calculated ignoring changes in live weight.

Chemical analyses of the feed and faecal samples, and milk urea measurement were made as reported previously by Huhtanen and Heikkilä (1996). Total N concentrations in fresh silage samples were measured by the Kjeldahl method using $\mathrm{Cu}$ as a digestion catalyst and a Tecator 1028 Dis- 


\section{AGRICULTURAL AND FOOD SCIENCE}

Jaakkola, S. et al. Whole-crop silage for dairy cows

tilling Unit. In Exp. 1 starch concentrations in feed and faecal samples were measured as described by Bach Knudsen et al. (1987). In Exp. 2 and 3 starch concentrations were analysed by the method of McCleary et al. (1994) with assay format 2 without pullulanase/ $\beta$-amylase treatment. A modification of the pepsin-cellulase method (Friedel 1990) described by Nousiainen et al. (2003) was used to measure in vitro OM digestibility of the forages. The results were calculated with a correction equation to convert pepsin-cellulase solubility values into in vivo digestibility by equations based on a data set consisting of Finnish in vivo digestibility trials (Huhtanen et al. 2006). The concentration of indigestible NDF in silages was measured as described by Ahvenjärvi et al. (2006).

\section{Statistical analysis}

Measurements collected during the sampling period were used when calculating the feed intake and milk production results. Experimental data was subjected to Analysis of Variance using the General Linear Model procedure (PROC GLM) of the Statistical Analysis Systems Institute $\left(\mathrm{SAS}^{\circledR}, 1989\right)$. The statistical model was $\mathrm{y}_{\mathrm{ijkl}}=\mu+\mathrm{B}_{\mathrm{i}}+\mathrm{C}(\mathrm{B})_{\mathrm{ij}}+\mathrm{P}_{\mathrm{k}}+\mathrm{T}_{1}$ $+(\mathrm{B} \times \mathrm{P})_{\mathrm{ik}}+(\mathrm{B} \times \mathrm{T})_{\mathrm{il}}+\mathrm{e}_{\mathrm{ijkl}}$, where $\mathrm{B}, \mathrm{C}(\mathrm{B}), \mathrm{P}$, and $\mathrm{T}$ are the effects of block, cow within block, period, and treatment, respectively, and eijkl is the error term. Treatment carry-over effect was included for milk production and feed consumption data, but no significant effects were found.

Sums of squares for treatment effects were further separated using orthogonal contrasts into single degree of freedom comparisons. In Exp. 1 the comparisons for the main effects were the protein supplement (Prot) and the linear (L), quadratic (Q) and cubic $(\mathrm{C})$ effect of the barley silage proportion in the silage mixture. The interactions were Prot $x$ L, Prot $\times$ Q and Prot $\times$ C. In Exp. 2 the comparisons for the main effects were the concentrate type (Conc), the L and Q effects of barley growth stage, and grass silage vs. BS2 silage. The interactions were Conc $\times$ L, Conc $\times$ Q and Conc $\times$ (grass silage vs. BS2). In Exp. 3 the comparisons for the main effects were the concentrate level (Conc), grass silage vs. cereal silages, barley silage vs. wheat silage, and the effect of growth stage of barley and wheat. The interactions were Conc $\times$ (grass vs. cereal), Conc $\times$ (barley vs. wheat) and Conc $\times$ growth stage. The results of the main treatment effects of Exp. 2 and 3 are presented in the tables. Only a few significant interactions were observed and they are mentioned in the text.

\section{Results}

\section{Silages}

The chemical composition of the barley, wheat and grass ensiled, and the respective silages are shown in Table 1 and that of the concentrates in Table 2. During harvesting at the dough stage the DM concentration of barley varied between 282 and $441 \mathrm{~g} \mathrm{~kg}^{-1}$, and that of wheat between 289 and $378 \mathrm{~g} \mathrm{~kg}^{-1}$. The proportion of ear increased with the advancing maturity of barley from 510 to 660 $\mathrm{g} \mathrm{kg}^{-1} \mathrm{DM}$ in Exp. 2 and from 460 to $560 \mathrm{~g} \mathrm{~kg}^{-1}$ $\mathrm{DM}$ in Exp. 3. In wheat the proportion of ear corresponded to the values observed with barley (Exp. 3). The height of barley was in Exp. 2 much lower than that of barley and wheat in Exp. 3 .

The advancing maturity had a minor effect on cereal crude protein concentration, which was on average $110 \mathrm{~g} \mathrm{~kg}^{-1} \mathrm{DM}$ in barley (Exp. 1-3) and $115 \mathrm{~g} \mathrm{~kg}^{-1} \mathrm{DM}$ in wheat (Exp. 3) at harvest. The concentration of NDF in barley was much lower in Exp. 2 (mean $420 \mathrm{~g} \mathrm{~kg}^{-1} \mathrm{DM}$ ) than in Exp. 1 and $3\left(522 \mathrm{~g} \mathrm{~kg}^{-1} \mathrm{DM}\right)$ whereas the starch concentration was higher in Exp. 2 (mean 212 vs. $121 \mathrm{~g}$ $\mathrm{kg}^{-1} \mathrm{DM}$ ). The harvest time had only a minor effect on the NDF concentration, whereas the starch concentration increased from 156 to $278 \mathrm{~g} \mathrm{~kg}^{-1}$ DM in Exp. 2, and from 61 to $160 \mathrm{~g} \mathrm{~kg}^{-1} \mathrm{DM}$ in Exp. 3 in barley, and from 67 to $196 \mathrm{~g} \mathrm{~kg}^{-1} \mathrm{DM}$ in wheat (Exp. 3). The change was reflected as a decrease in the concentration of water soluble carbohydrates. 


\section{AGRICULTURAL AND FOOD SCIENCE}

Vol. 18 (2009): 234-256.

The DM concentration of grass was similar in all experiments (mean $246 \mathrm{~g} \mathrm{~kg}^{-1}$ ). Compared to cereals, grass had higher concentration of crude protein (from 111 to $138 \mathrm{~g} \mathrm{~kg}^{-1} \mathrm{DM}$ ) and NDF (from 502 to $586 \mathrm{~g} \mathrm{~kg}^{-1} \mathrm{DM}$ ). Indigestible NDF concentration was distinctly higher in cereal crop silages than in grass silages in Exp. 1 and 3. However, in Exp. 2 no difference was observed between the second cut grass silage and whole crop barley silages. Advanced maturity increased (Exp. 3 barley) or slightly decreased (Exp. 2 barley, Exp. 3 wheat) the iNDF concentration of silage.

The starch concentrations of whole crop silages after the ensiling period were in some silages slightly lower than those of the parent material while NDF and WSC concentrations clearly decreased during fermentation process. Exception was NDF concentration in BS1, and WSC concentration in BS2 and WS2 (Exp. 3).

The fermentation quality of whole crop silages was good in all experiments, as evidenced by low $\mathrm{pH}$ and concentrations of VFA (Table 1). Only traces of butyric acid were observed. Compared to whole crop silages, grass silages were of similar good fermentation quality. In Exp. 2 harvesting barley at the late dough stage (BS3) resulted in higher $\mathrm{pH}$ and WSC concentration, and more restricted fermentation as compared with other barley silages. No effects of the harvest time on the proportion of ammonia $\mathrm{N}$ in the barley silage were observed. In wheat silages the ammonia-N proportion was higher than in barley silages and higher in WS2 than in WS1 (90 vs $66 \mathrm{~g} \mathrm{~kg}^{-1} \mathrm{~N}$ ).

In Exp. 1 the $\mathrm{CP}$ concentration of protein supplemented concentrate (+RSM) was $164 \mathrm{~g}$ $\mathrm{kg}^{-1} \mathrm{DM}$, clearly higher than that of the control concentrate (110 $\left.\mathrm{g} \mathrm{kg}^{-1} \mathrm{DM}\right)$. In Exp. 2 and 3, concentrate $\mathrm{CP}$ concentration was higher (mean $202 \mathrm{~g} \mathrm{~kg}^{-1} \mathrm{DM}$ ) than in Exp. 1. In Exp. 2 the use of different ingredients resulted in lower starch concentration in $\mathrm{CC}$ than in FC concentrate. However, there was no difference in the NDF concentration.

\section{Feeding experiment I}

The inclusion of barley silage in the diet tended $(p<0.10)$ to change silage DM intake in a quadratic manner, such that the intake was highest with the BS20 and lowest with the BS60 diet (Table 3). Diet $\mathrm{OM}, \mathrm{NDF}$ and CP digestibility decreased linearly ( $p$ $<0.001$ ) with the increasing proportion of barley silage. Protein supplementation increased significantly silage intake $(p<0.001)$ and OM, NDF $(p<0.01)$ and $\mathrm{CP}(p<0.001)$ digestibility. However, the increase in OM digestibility was different with different silage diets (interaction RSM $\times$ BS cubic). Due to the changes in intake and digestibility, inclusion of barley silage linearly decreased $(p<0.001)$ and that of RSM increased $(p<0.001) \mathrm{ME}$ and AAT intake.

Milk and milk constituent yields decreased linearly $(p<0.001)$ with the increasing proportion of barley silage in the diet, and increased $(p<0.001$, $p<0.01$ ) with the inclusion of RSM in the diet (Table 4). A significant interaction between BS cubic effect and RSM was observed in milk fat concentration $(p<0.05)$. Rape seed meal increased $(p<0.001)$ milk protein and urea concentrations, while replacing grass silage with barley silage decreased linearly $(p<0.01)$ milk urea concentration.

The efficiency of dietary $\mathrm{N}$ utilization, assessed as the ratio of milk N/N intake, decreased linearly with the increasing rate of barley silage in the diet $(p<0.05)$ but no effect in AAT and ME utilization was observed. The use of RSM decreased the ratio of milk N/N intake $(p<0.001)$ but increased AAT utilization $(p<0.001)$. The efficiency of ME utilization decreased $(p<0.05)$ with RSM supplementation. Feed efficiency, assessed as the ratio of $\mathrm{kg}$ $\mathrm{ECM} \mathrm{kg}{ }^{-1} \mathrm{DM}$ intake, decreased linearly with the increasing proportion of barley silage.

\section{Feeding experiment 2}

Harvesting barley at one week intervals had no effect on silage DM intake $(p>0.05)$ whereas the starch intake increased linearly $(p<0.001)$ (Table 5$)$. Cows fed the grass silage diet ate more NDF $(p<0.001)$ and ME $(p<0.05)$ but less starch $(p<0.001)$ than those 


\section{AGRICULTURAL AND FOOD SCIENCE}

Jaakkola, S. et al. Whole-crop silage for dairy cows

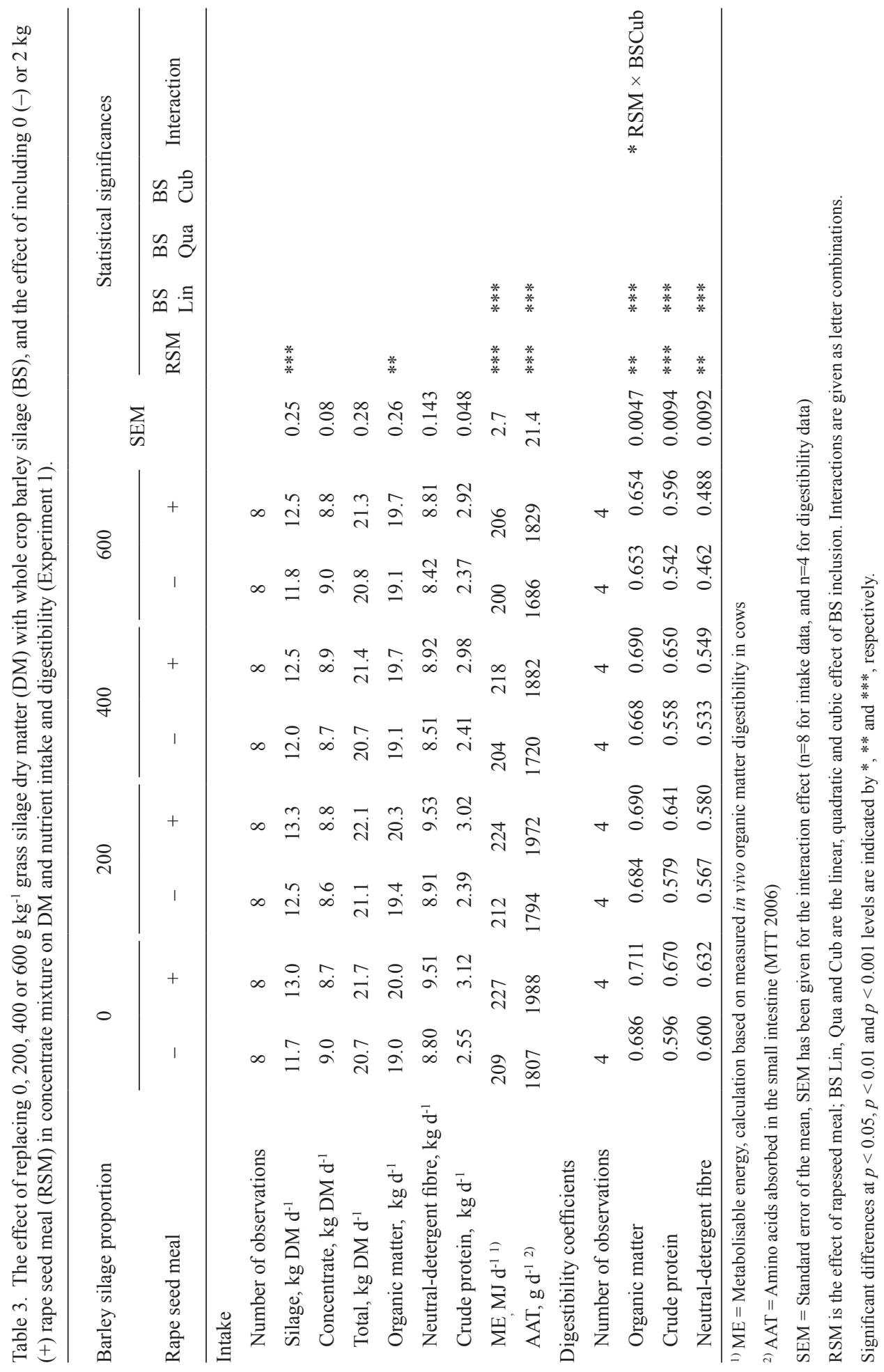


Vol. 18 (2009): 234-256.

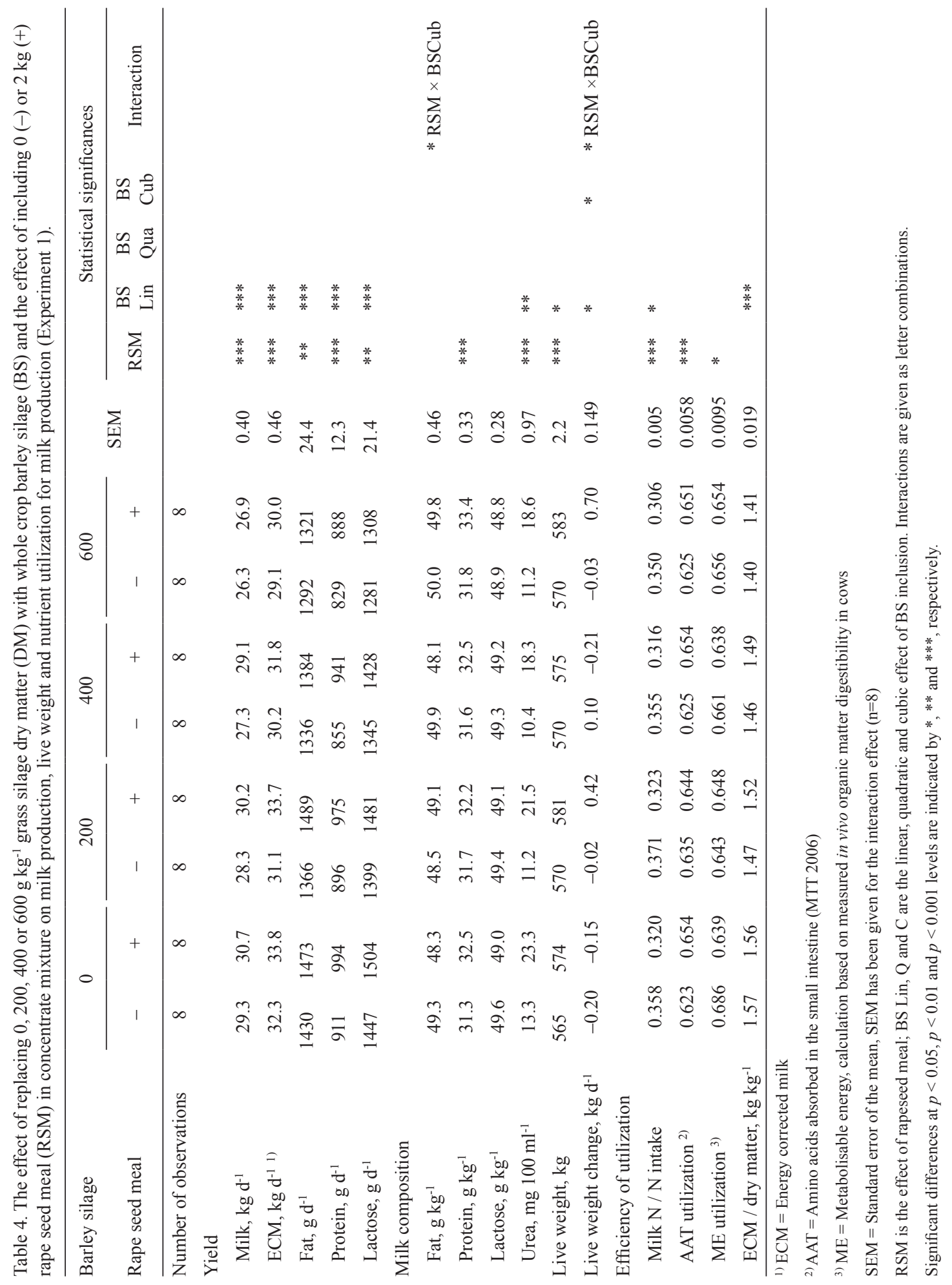


Jaakkola, S. et al. Whole-crop silage for dairy cows

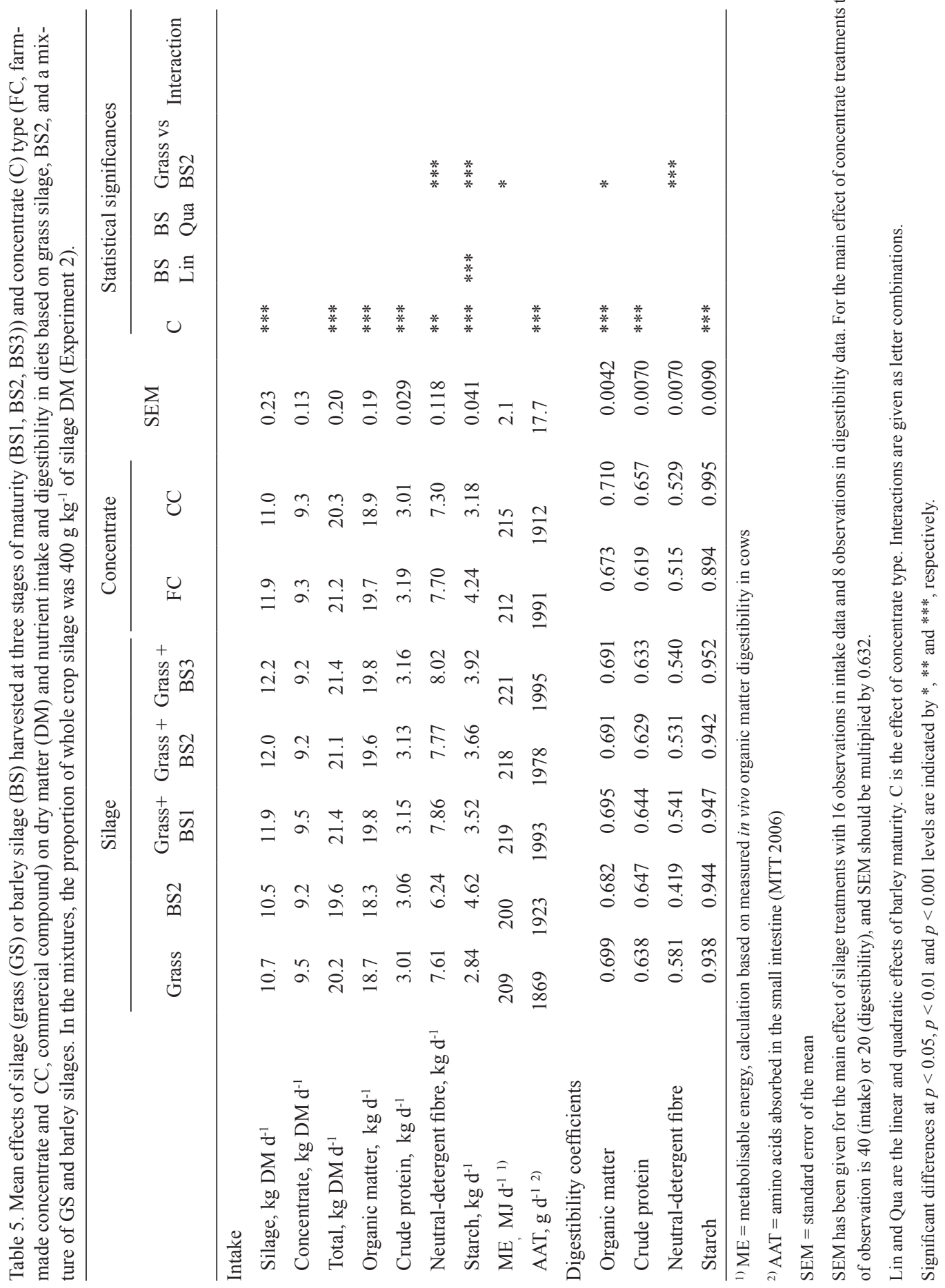




\section{AGRICULTURAL AND FOOD SCIENCE}

Vol. 18 (2009): 234-256.

fed the barley silage diet (BS2). The digestibilities of OM $(p<0.05)$ and NDF $(p<0.001)$ were lower on the BS2 diet than on the GS diet.

Feeding of farm-made starch based concentrate resulted in higher silage and total DM intake and lower OM, CP and starch digestibility $(p<0.001)$ compared with CC-concentrate. As a result, the intakes of NDF $(p<0.01), \mathrm{OM}, \mathrm{CP}$, starch and AAT $(p<0.001)$ were higher with the FC diet, but no difference was observed in ME intake.

The same milk, ECM, fat and lactose yield was obtained with GS and BS2 diets (Table 6). However, feeding BS2 resulted in a higher milk protein concentration $(p<0.001)$ and protein yield $(p<0.05)$ than feeding GS.

No difference was observed between the concentrate types in milk or ECM yield ( $p>0.05)$. Milk protein concentration and yield increased with increasing maturity on the FC diet and decreased on the $\mathrm{CC}$ diet (interaction $\mathrm{C} \times \mathrm{BSL} p<0.05$ ). On the FC diet milk protein concentration was 33.6, 34.1 and $34.3 \mathrm{~g} \mathrm{~kg}^{-1}$ on diets $\mathrm{G}+\mathrm{BS} 1, \mathrm{G}+\mathrm{BS} 2, \mathrm{G}+\mathrm{BS} 3$, respectively. On the $\mathrm{CC}$ diet the values were 33.3, 34.0 and 32.6, respectively. Milk lactose concentration was higher on the $\mathrm{CC}$ than $\mathrm{FC} \operatorname{diet}(p<0.05)$. The cows gained more weight with $\mathrm{FC}$ than $\mathrm{CC}$ concentrate $(p<0.05)$.

Nitrogen and AAT utilization was more efficient with cows eating $\mathrm{CC}$ rather than $\mathrm{FC}$ concentrate $(p<0.001, p<0.01)$. In ME utilization the cows having the $\mathrm{FC}$ diet were more efficient than those on the $\mathrm{CC}$ diet, although the value of $\mathrm{kg} \mathrm{ECM} \mathrm{kg}^{-1} \mathrm{DM}$ intake was higher with $\mathrm{CC}(p<0.001)$. When comparing GS and BS2 diets, the $\mathrm{k}_{1}$ value was higher on the BS2 diet with CC concentrate whereas only a small difference was observed with the FC diet (interaction $\mathrm{C} \times \mathrm{GS} v s$. BS2, $p<0.05$ ). The $\mathrm{k}_{1}$ values were $0.620,0.584,0.631$ and 0.642 on diets GSFC, GS-CC, BS2-FC and BS2-CC, respectively. For kg ECM kg ${ }^{-1} \mathrm{DM}$ intake the respective values were $1.39,1.40,1.38$ and 1.50 (interaction $\mathrm{C} \times \mathrm{GS}$ vs. $\mathrm{BS} 2, p<0.01)$.

\section{Feeding experiment 3}

Compared to the grass silage diet, whole crop silage diets had, on average, lower digestibility of OM and NDF $(p<0.001)$ (Table 7). However, lower digestibility was compensated by increased silage and total DM intake on mixed diets $(p<0.001)$. Consequently, the intakes of OM and starch $(p<0.001)$ and that of NDF $(p<0.05)$ were higher with mixed diets than with the GS diet.

The intakes of NDF $(p<0.05)$ and $\operatorname{ME}(p<0.01)$ were higher with the BS diet than with the WS diet, the latter being related to the lower ME intake of the WS1 compared to the WS2 diet $(p<0.01)$. The advancing maturity resulted in increased starch intake for both BS and WS diets $(p<0.001)$. The digestibility of NDF was higher with the BS than the WS diet $(p<0.05)$.

An increase in concentrate feeding induced a higher $(p<0.001)$ total DM intake, which was associated with a reduction in silage DM intake $(p<0.001)$. Similarly, the intakes of OM, CP, starch, $\mathrm{ME}$ and AAT increased with the increasing concentrate proportion $(p<0.001)$. The use of higher concentrate amount resulted in decreased digestibility of diet NDF $(p<0.05)$.

The inclusion of whole crop silage in the grass silage diet had no effect on milk or milk components yields, or milk composition (Table 8). Neither were there any differences between the BS and WS diets, or between growth stages of barley. With wheat silages, the WS2 diet increased ECM yield compared to the WS1 diet $(p<0.05)$. Milk urea concentration was lower with the GS diet than with mixed diets, which was explained by the higher $\mathrm{CP}$ concentration in the wheat silage diets as compared with barley silage diets $(p<0.001)$.

An increase in concentrate amount induced higher milk, ECM, milk fat, protein and lactose yields $(p<0.001)$. In addition, high concentrate amount resulted in increased milk protein and urea $(p<0.001)$ and lactose $(p<0.05)$ concentrations. Further, higher live weight gain was observed with higher concentrate amount $(p<0.01)$.

Minor differences were observed between the silage diets in the efficiency of nitrogen and ME utilization. The only differences were between the 
Jaakkola, S. et al. Whole-crop silage for dairy cows

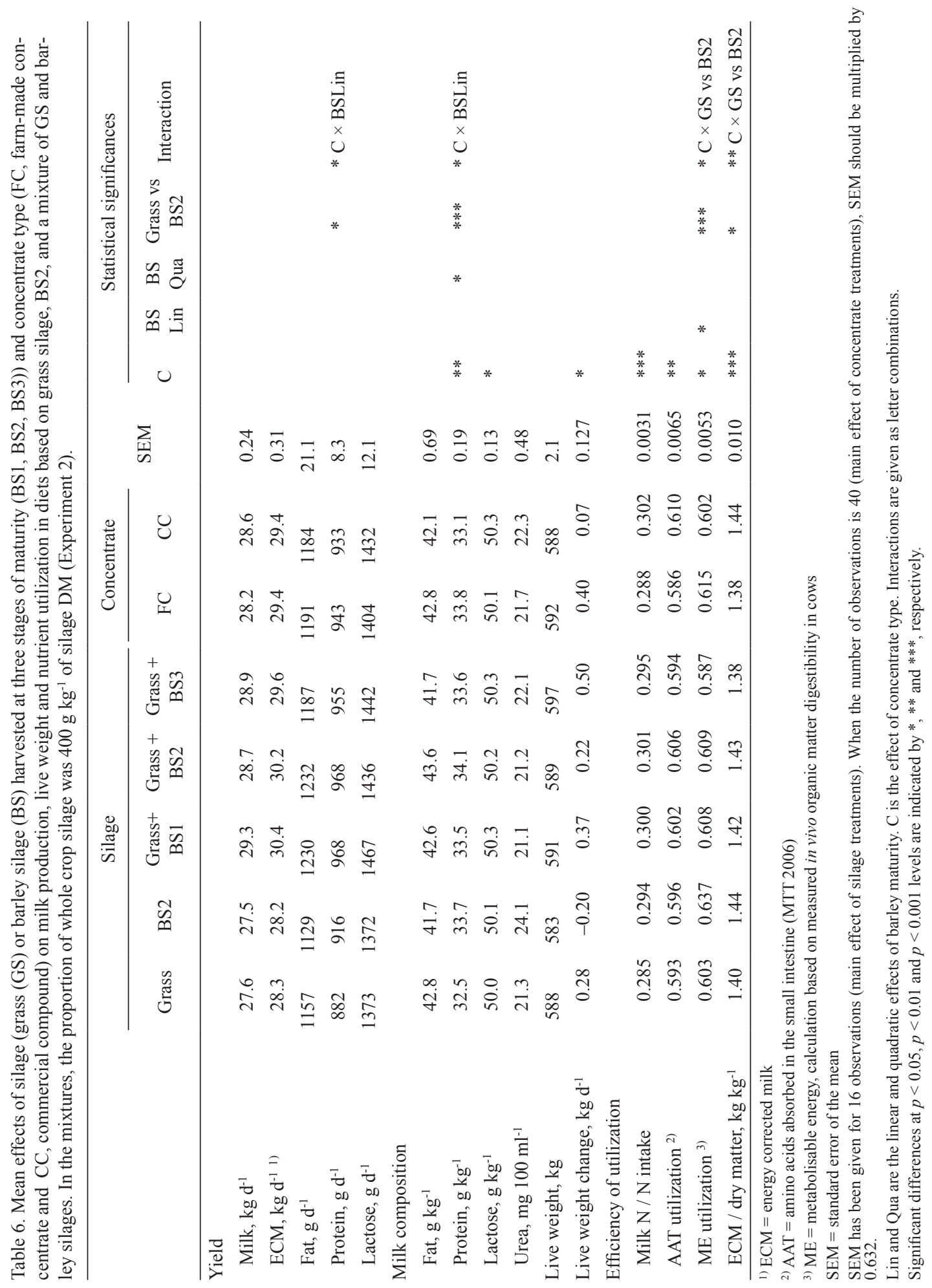


Vol. 18 (2009): 234-256.

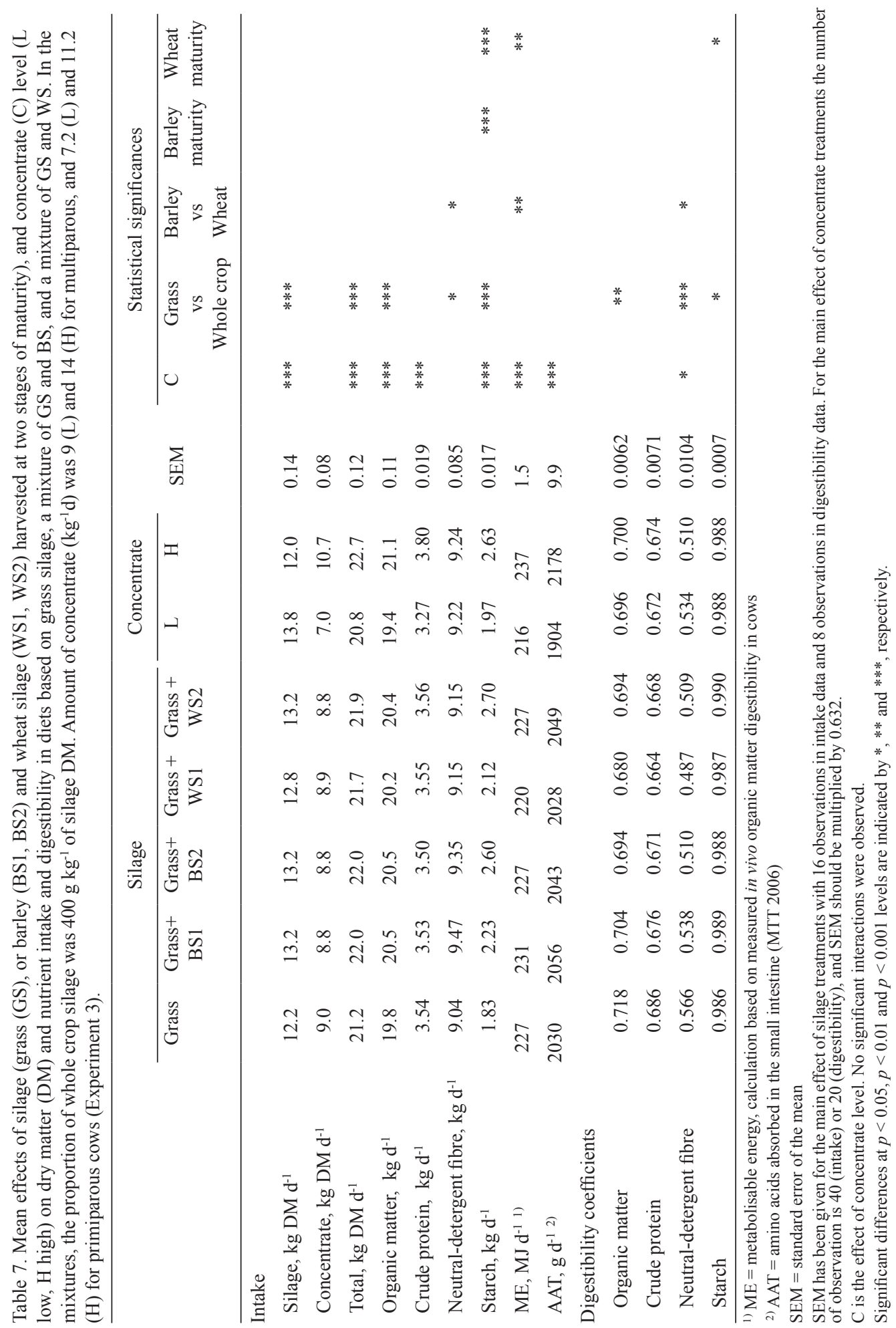


Jaakkola, S. et al. Whole-crop silage for dairy cows

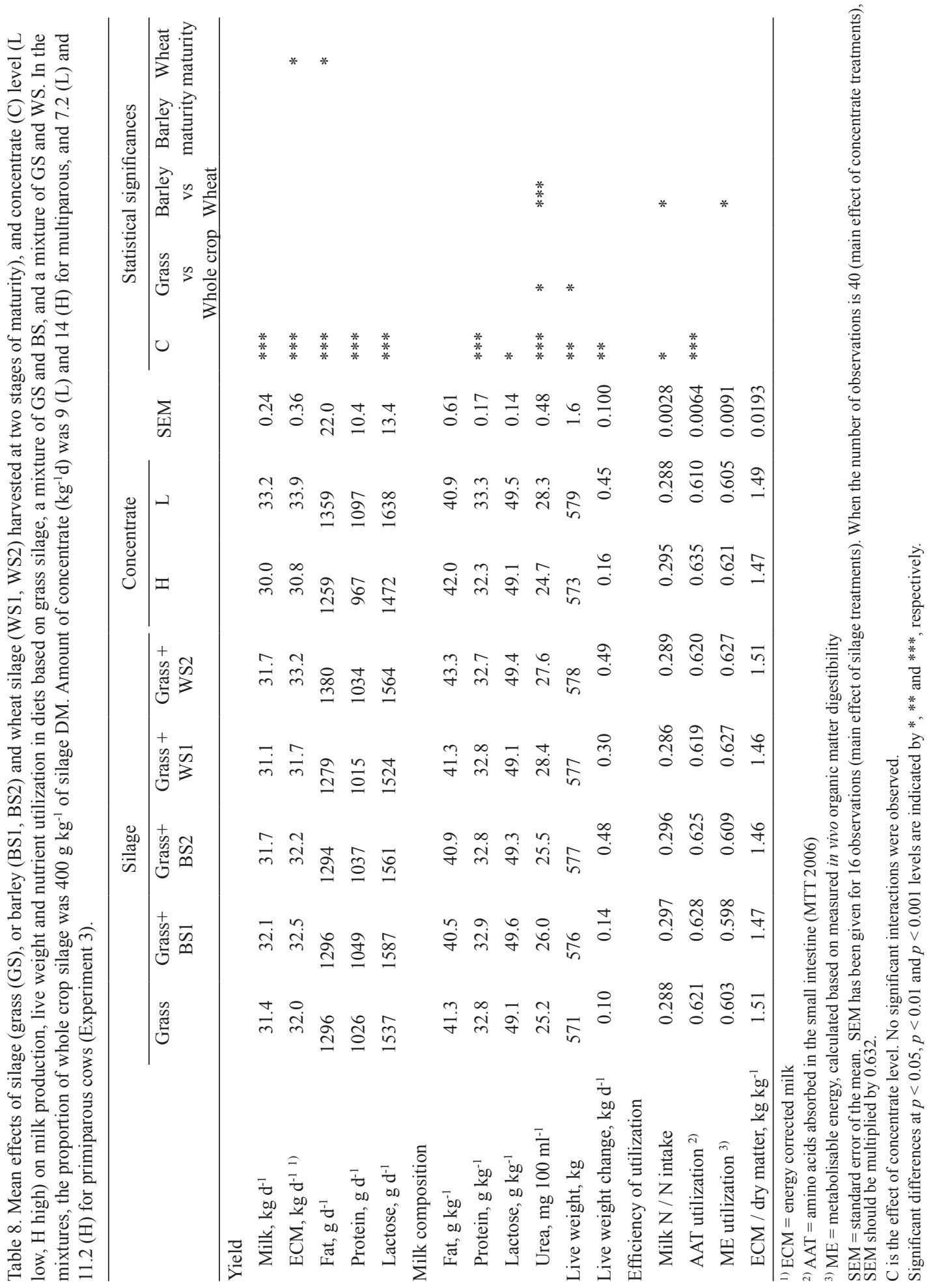




\section{AGRICULTURAL AND FOOD SCIENCE}

Vol. 18 (2009): 234-256.

cereal silages since the efficiency of dietary nitrogen utilization (milk N/N intake) was higher with barley than with wheat silage, whereas ME utilization was higher with wheat silage $(p<0.05)$. Increasing concentrate amount resulted in decreased efficiency of $\mathrm{N}(p<0.05)$ and AAT $(p<0.001)$ utilization.

\section{Discussion}

\section{Chemical composition of crops at harvest and after ensiling}

Advancing crop maturity increased the proportion of ear and the concentration of starch in barley and wheat, while minor changes were observed in NDF and crude protein concentrations. Compared to some other studies, the decrease in NDF concentration of wheat was relatively small (Kristensen 1992, Sutton et al. 2002). The timing and interval of harvests, and climatic factors, such as light intensity and temperature, affect the extent of compositional changes in cereals explaining the variation within the experiments. Chow et al. (2008) reported that delaying the planting day of barley altered barley's growing environment (temperature, precipitation) and affected nutrient composition and in vitro NDF digestibility.

The NDF concentration was much lower in whole crop cereals than in grass, whereas the concentration of iNDF measured in WC silages in Exp. 1 and 3 was at least twice as high as in grass silage. In Exp. 2, the iNDF concentration of barley silage was exceptionally low, which can be due to the low straw proportion in dry and warm climatic conditions, and probably to the low lignification of straw in relation to grain development. The mean temperature of June and July during Exp. 2 was 2.9 and $3.9^{\circ} \mathrm{C}$ higher than during Exp. 1 and Exp. 3, respectively. Further, the precipitation was 109 and $86 \mathrm{~mm}$ less, respectively.

The increase in starch concentration of cereal crops with the advancing maturity was associated with a decrease in WSC concentration, which resulted in minor increases (from 34 to $43 \mathrm{~g} \mathrm{~kg}^{-1} \mathrm{DM}$, Exp. 2 and Exp. 3) in the concentration of total nonstructural carbohydrates (NSC, starch + WSC). Hill and Leaver (1999a) reported lower concentrations of WSC in wheat at milk/early dough stages and the concentration appeared to decline faster than in the present experiment. A summary of the results of MacGregor and Edwards (1968) showed that the WSC concentration of barley reached a peak value (326 g kg-1 DM) at the milky ripe stage of growth when the DM concentration was $290 \mathrm{~g} \mathrm{~kg}^{-1}$. In spring wheat, WSC concentration remained high (140 to $250 \mathrm{~g} \mathrm{~kg}^{-1} \mathrm{DM}$ ) until 4 to 5 weeks after the start of heading, after which it fell sharply (Kristensen 1992).

The variability of the starch concentration at the dough stage agrees with the results reported in the Nordic countries at the same growth stage (Kristensen 1992, Nadeau 2007, Wallsten et al. 2009). Comparison of different studies is, however, challenging since the deposition of sugar to starch depends on many factors. Givens et al. (1993) suggested that the assessment of growth stage alone may not be a good guide to the composition and digestibility of whole crop cereals. In the present experiment the ratio of NSC to NDF in barley seemed to be consistently more affected by the between-year differences in the climatic conditions than by the stage of maturity. The length and proportion of straw was exceptionally small and starch concentration high in Exp. 2. As a result the mean concentration of NSC was $150 \mathrm{~g} \mathrm{~kg}^{-1} \mathrm{DM}$ higher and NDF concentration $95 \mathrm{~g} \mathrm{~kg}^{-1} \mathrm{DM}$ lower in Exp. 2 than Exp. 3. Emphasizing the difficulties in controlling cereal development, the results of Sutton et al. (2002) showed that the crops may be physiologically at different maturity stages at the same DM concentration. Among other factors, the harvesting technique may affect the carbohydrate composition. Sinclair et al. (2003) reported that increasing cutting height (stubble heights 18 vs 38 $\mathrm{cm}$ ) increased starch concentrations from 232 to $292 \mathrm{~g} \mathrm{~kg}^{-1} \mathrm{DM}$ and reduced NDF from 433 to 384 $\mathrm{g} \mathrm{kg}^{-1} \mathrm{DM}$.

The changes in starch concentration during ensiling were inconsistent, reflecting mainly the 


\section{AGRICULTURAL AND FOOD SCIENCE}

Jaakkola, S. et al. Whole-crop silage for dairy cows

difficulties in taking representative samples rather than e.g. degradation of starch. Since the use of starch by lactic acid bacteria is limited the possible losses of starch may be due to the utilization by yeasts and fungi, plant respiration, and solubilisation (McDonald et al. 1991).

\section{Fermentation quality of forages}

The fermentation quality of whole crop silages was good as evidenced by the low $\mathrm{pH}$ and small amounts of VFA. No problems were observed regarding the aerobic stability of silages but it should be noted that the experiments were conducted at winter time when low temperatures decrease the susceptibility to aerobic deterioration. The formic acid based additives restricted fermentation equally well in grass and whole crop silages. Based on the ratio of WSC to lactic acid, the fermentation was slightly more restricted in grass silage as compared to WC silages harvested at the early dough stage. Due to the increasing DM concentration with advancing maturity, the fermentation in later harvested cereal silages was less extensive than in grass silages. The DM losses and protein degradation caused by fermentation may be substantial in whole crop silages of low DM (Tetlow 1992). The results observed here suggest that the losses may be decreased by a formic acid based additive and/or postponing the harvest until the late dough stage.

Formic acid is known to inhibit protein degradation and lactic acid fermentation during ensiling. The changes in the ratio of silage WSC to lactic acid affect the nutrient supply to the rumen microbes, and subsequently modify the microbial protein synthesis and molar proportions of VFA in the rumen (Jaakkola et al. 2006a) and affect milk production (Jaakkola et al. 2006b). With cereal silage, the intake of starch further complicates the nutrient supply and modifies the rumen fermentation pattern. The total amount of NSC in whole crop silages varied between 108 and $353 \mathrm{~g} \mathrm{~kg}^{-1}$ DM being much higher than the typical values of restrictively fermented grass silages $\left(53-82 \mathrm{~g} \mathrm{~kg}^{-1}\right.$ DM).

\section{Growth stage and cereal type}

Lignin deposition characterizes the process of maturation of the straw of small grain cereals. In terms of whole crop digestibility, lignification is compensated by grain development and deposition of starch. This explains why within the two weeks interval no effects of barley or wheat maturity on diet digestibility were observed in Exp. 2 and 3. Inconsistent effects of wheat maturity on diet digestibility have been reported (Südekum and Arndt 1998, Sutton et al. 2002). Decreased or increased digestibility with advancing maturity may be attributed to the specific stage of growth and characteristics of the crops as well as to the method used in the digestibility measurement. In the early stages of a crop maturity from heading to early dough stage the $\mathrm{OM}$ digestibility has decreased in sheep offered wheat silage (Crovetto et al. 1998) and in dairy cow offered barley silage (Wallsten and Martinsson 2009). At that stage the starch formation is still limited while the digestibility of NDF decreases. With advancing maturity the increase in the concentration of starch results in a recovery of crop OM digestibility (Sutton et al. 2002). With high DM wheat the increases in OM digestibility have been attributed to urea treatment (Tetlow 1992) and decreases in starch digestibility to the hard cereal grains which are poorly digested by dairy cows (Sutton et al. 1997, Abdalla et al. 1999, Sutton et al. 2002).

No differences were observed in silage DM intake with advancing maturity of barley or wheat (Exp. 2, Exp. 3) or between barley and wheat (Exp. 3). Sutton et al. (2002) noted increased intake with advancing wheat maturity, which might be attributed to a much greater difference between the maturity stages (DM $300 \mathrm{vs} 580 \mathrm{~g} \mathrm{~kg}^{-1}$ ) and the extent of silage fermentation than in the present experiment. However, they reported no effects of maturity on milk yield. In the present experiments, harvesting barley at one week (Exp. 2) or two week (Exp. 3) intervals had no significant effect on milk or milk component yields. The result indicates flexibility in the timing of harvest during dough stage of whole crop as timing is not as critical for the nutritive value as in case of grass. On the basis of the maxi- 


\section{AGRICULTURAL AND FOOD SCIENCE}

Vol. 18 (2009): 234-256.

mal crop yield the optimal harvest dates were at the soft/hard dough stage of barley.

Higher ECM yield with WS2 than with WS1 diet was associated with a slightly higher diet OM digestibility $(\mathrm{P}=0.147)$ and milk fat concentration (41.3 vs $43.3 \mathrm{~g} \mathrm{~kg}$ ). The result suggests that the later harvest time for wheat was more optimal in terms of both crop yield and ECM yield. This is in accordance with other studies showing increased crop yield of wheat with advancing maturity before stabilizing at DM concentrations of about $400 \mathrm{~g}$ DM per kg (Tetlow 1992, Kristensen 1992, Sutton et al. 2002). In barley the maximum yield is obtained at DM concentration of approximately 350 $\mathrm{g} \mathrm{kg}^{-1}$ or 4-5 weeks after the initial ear emergency according to Kristensen (1992).

\section{Dietary inclusion rate of whole crop barley and wheat silages}

The large variation in the characteristics of whole crop silages suggests that the production responses can be attributed to the variable composition of rumen fermentable carbohydrates of silages. Inclusion of whole crop silage in the silage mixture increased (Exp. 2 and 3) or had a minor effect (Exp. 1) on the intake of silage. Unlike with grass silage (Rinne et al. 1999), the intake responses could not be associated with forage digestibility. Even when the diet digestibility clearly decreased (Exp. 1) with the increasing proportion of whole crop barley silage, no corresponding negative effects on silage intake were observed. Increased intakes with a mixture of grass and WC silage have been observed both with fermented and urea treated wheat silage (Sutton et al. 1997, Abdalla et al. 1999, Sinclair et al. 2003). In the experiment of Hameleers (1998), the response was achieved when WC silage was of later maturity and grass silage of higher ME value than in the present experiment. Also the response has been realized with grass silage of poorer fermentation quality (ammonia N $128 \mathrm{~g} \mathrm{~kg}^{-1} \mathrm{~N}$ ) (Phipps et al. 1995). In a data analysis by Huhtanen et al. (2007), responses to replacing grass silage partially or totally with whole-crop silage could not be accurately predicted from differences in silage digestibility, DM concentration or fermentation quality, and the observed silage DM intake was generally higher than the predicted intake.

Ahvenjärvi et al. (2006) examined the silages of Exp. 1 in a physiological study in cows equipped with rumen cannulas. They concluded that the characteristics of whole crop cereals allow cows more flexibility in regulating intake in relation to energy demand than grass silage. The lower NDF concentration of WC silage may be one reason for that (Huhtanen et al. 2007) since the animals were able to increase ruminal NDF pool at lower inclusion rates (0.2 and 0.4) (Ahvenjärvi et al. 2006). In Exp. 2, the NDF concentration of GS was 147 $\mathrm{g} \mathrm{kg} \mathrm{DM}^{-1}$ higher than the mean concentration in WC silages, which resulted in a higher silage-NDF concentration in the diets of GS alone than in the diets based on the mixtures of grass and whole crop silage (277 vs $210 \mathrm{~g} \mathrm{~kg} \mathrm{DM}^{-1}$ ).

The responses in intake to physical treatment of barley silage have also been studied. Soita et al. $(2002,2003)$ showed that reducing the chop length of barley silage increased feed intake in steers, while the effect depended on the concentrate level of the diet. Despite changes in chemical composition, elevating the cutting height of wheat or barley did not improve or even decreased intake and animal performance in cows (Sinclair et al. 2003, Jackson et al. 2004) or in beef cattle (Walsh et al. 2009). Neither did the mechanical processing of barley silage affect its nutritive value in dairy cow diet (Eun et al. 2004). In the present study, the cutting height was the same in all experiments. The particle size of the silage was longer in Exp. 1 than in other experiments due to the different harvester (particle size not measured). Although the mechanical treatment of silage during harvest may have some effect, the assessment of the importance of the chop lengths/types is not possible in the present study. The use of a mixer wagon in all experiments further affected the particle size of the silages.

The nutritive value of the control grass silage compared to the WC silage may partly explain the variation in the milk yield responses. The energy value of GS was higher in Exp. 1 (10.8 ME MJ 


\section{AGRICULTURAL AND FOOD SCIENCE}

Jaakkola, S. et al. Whole-crop silage for dairy cows

$\mathrm{kg}^{-1} \mathrm{DM}$ ) and Exp. 3 (10.9) than in Exp. 2 (10.4). Much of the poor milk yield response to whole crop silage inclusion in Exp. 1 can be ascribed to its low digestibility as compared with grass silage. Ahvenjärvi et al. (2006) noted that the decreases in OM and NDF digestibility were attributed to the higher iNDF concentration of barley silage compared to that of grass silage. Decreased microbial $\mathrm{N}$ flow from the rumen further explained the poor milk responses to barley silage. However, the iNDF concentration of WC silages in Exp. 3 was also twice as high as in GS (65 vs $143 \mathrm{~g} \mathrm{~kg}^{-1} \mathrm{DM}$ ) but the intake of grass and WC silage mixtures was significantly higher than that of GS, and milk yield unchanged. Thus, the response to WC silage might also be attributed to other factors than the fibre characteristics of GS and WCS.

In the physiological study the daily averages of ruminal ammonia concentrations were lower (Ahvenjärvi et al. 2006) than the suggested minimum levels for optimum fibre digestion (Hoover 1986). It is possible that the rumen degradable $\mathrm{N}$ limited the microbial activity, especially with higher inclusion rates of WC. In Exp. 3, more positive milk yield response to feeding WC silage was observed, when the diet CP concentration was higher than in the protein supplemented diet in Exp. 1 (140 vs 162 $\left.\mathrm{g} \mathrm{CP} \mathrm{kg}{ }^{-1} \mathrm{DM}\right)$. There was a substantial difference in CP concentration of concentrate (160 vs $210 \mathrm{~g}$ $\mathrm{kg}^{-1} \mathrm{DM}$ ) between the studies, which may explain the difference in milk yield response. The proportion of concentrate in diet DM was the same in both experiments (415 vs $407 \mathrm{~g} \mathrm{~kg}^{-1}$ ).

The same milk yield with GS and BS2 in Exp. 2 suggests that the silages had similar energy value. This corresponds well with the same iNDF concentration of the forages but was associated with significantly lower OM and NDF digestibility of the BS2 diet than the GS diet. However, cows having a mixture of GS and BS2 produced on average 2.0 $\mathrm{kg}$ more ECM than those having only GS or BS2. The synergistic effect of feeding mixture suggests that the nutrient balance might be better than when silages were fed alone. Studies on rumen fermentation have shown inconsistent results. The proportion of acetate was lower and that of propionate higher in cows consuming WC silages rather than alfalfa or grass silage (Khorasani et al. 1996, Ahvenjärvi et al. 2006) or rumen acetate or butyrate has increased after inclusion of WC in the $\operatorname{diet}(\mathrm{Ab}-$ dalla et al. 1999, Owens et al. 2008). In Exp. 3, daily DM intake on mixed silage diets was $0.7 \mathrm{~kg}$ higher than that of the GS diet, compensating the decreased digestibility. This resulted in equal milk yield with the mixed and GS diets. Similarly, the increased feed intake of silage mixtures has not led to corresponding increases in milk yield in other experiments (Leaver and Hill 1995, Phipps et al. 1995, Hameleers 1998).

Inclusion of WC silage in the diet had no effect on milk composition except in Exp. 2 in which milk protein concentration was higher with BS2 than with GS. Also in some earlier experiments protein concentration was higher with mixtures of grass silage and urea-treated whole crop wheat than with grass silage alone (Abdalla et al. 1999, Sutton et al. 2002).

Inclusion of barley silage in the diet decreased linearly $\mathrm{N}$ intake in Exp. 1 which explains the extremely low milk urea concentration. The high efficiency of $\mathrm{N}$ utilization in milk production is also attributed to the low $\mathrm{N}$ concentration of grass silage. In Exp. 2 and 3, due to the low $\mathrm{N}$ concentration of both grass and WC silages, N utilization was also good despite the high protein concentration of the concentrate.

\section{Amount and type of concentrate supplementation}

Silage DM intake increased by an average of $0.7 \mathrm{~kg}$ per day when rape seed meal was included in the WC diets, being less than with grass silage (1.3 kg, Exp. 1). In milk production the mean response to rape seed meal supplementation of the WC diet was $0.94 \mathrm{~kg}$ ECM and $41.5 \mathrm{~g}$ milk protein per $\mathrm{kg}$ DM of RSM. With the GS diet the values were $0.83 \mathrm{~kg}$ and 46.1 $\mathrm{g}$, respectively. The responses correspond well with the mean values in a literature review of rape seed meal studies in Finland (Huhtanen 1998) although the crude protein concentration of the control diets was exceptionally low (mean $117 \mathrm{~g} \mathrm{~kg}^{-1} \mathrm{DM}$ ). A vari- 


\section{AGRICULTURAL AND FOOD SCIENCE}

Vol. 18 (2009): 234-256.

ation was observed between the WC silages so that the highest responses in milk and protein yield were with BS20 silage (1.44 kg ECM) and BS40 (47.8 g protein), and the lowest with BS60 silage $(0.50 \mathrm{~kg}$ and $32.8 \mathrm{~g}$ ). Limited published data is available on the protein supplementation of barley silage. When urea treated whole-crop wheat was offered as a sole feed, additional protein supplement with fish meal but not with soya-bean meal increased milk yield (Hill and Leaver 1999b).

The mean daily starch intake in Exp. 2 was 1.1 $\mathrm{kg}$ lower in the diets including commercial compound than cereal based FC concentrate. Further, for the GS diet the mean daily starch intake was 1.8 $\mathrm{kg}$ lower than with the BS2 diet. The absence of interaction between concentrate and silage type indicates no benefit by supplementing cereal silages with low starch concentrates. Kristensen (1992) compared rolled barley, fodderbeet and dried sugar beet pulp as supplement for whole crop barley silage, and observed only minor effects on the production of milk and milk components. The lack of interaction in the present study may be associated with the concentration of total NSC in the concentrates, which was probably quite similar judging by the similar NDF concentration of concentrates (WSC not measured). In addition, there was no difference between the FC and CC diets in the proportion of silage-NDF concentration of the diet (224 vs $216 \mathrm{~g} \mathrm{~kg} \mathrm{DM}^{-1}$ ) which is considered to be an important criterion for optimal rumen function.

The cows offered FC concentrate ate significantly more silage than those having $\mathrm{CC}$ concentrate but there was no difference in milk yield due to the lower OM digestibility of the FC diet. The cows were able to compensate the lower digestibility of the FC diet by increasing silage intake. The low starch digestibility with the FC $\operatorname{diet}(0.89)$ suggests that some grain in the farm mixture remained intact after grinding. The reason for this is unlikely to be due to the WC starch digestibility since high starch digestibility with CC diet in Exp. 2, and with all diets in Exp. 3, indicates that starch of WC silages was completely digested.

The effects of concentrate level in Exp. 3 agree with the results of Hill and Leaver (1999b) who offered dairy cows urea treated whole crop wheat as a sole feed. In the present experiment, increasing the amount of concentrate decreased silage intake but total DM intake increased by $1.9 \mathrm{~kg}$ DM per day. With the mixture of GS and whole crop silages the substitution rate was $0.45 \mathrm{~kg}$ silage DM per $\mathrm{kg}$ concentrate DM and 0.59 with GS. The values are in good agreement with the mean value observed in studies with grass silage (Huhtanen 1998). Similarly, with whole crop wheat silage as the sole forage the substitution rate of concentrate was 0.59 (Hill and Leaver 1999b). The mean response in milk yield was 0.65 and $0.90 \mathrm{~kg}$ ECM per $\mathrm{kg}$ concentrate DM with grass silage and grass-whole crop silage mixtures, respectively, being higher than $0.52 \mathrm{~kg}$ in the experiment of Hill and Leaver (1999b). The result of the present experiments suggests that the responses to increased concentrate amount in the diets of mixed grass and WC silage are similar with diets based on grass silage as the sole forage.

\section{Conclusions}

Successful preservation can be achieved by preserving whole-crop barley and wheat with a formic acid based additive at dough stage with dry matter concentration of 300-450 $\mathrm{g} \mathrm{kg}^{-1}$. The results show that with barley, advancing maturity had no effect on milk yield, whereas with wheat silage harvest at soft/hard dough, rather than at early dough stage, increased milk yield. In terms of milk yield, the soft/hard dough stage is the optimal harvest time for both cereals.

Whole-crop cereals did not accomplish as high digestibility as is possible with grass silage. However, the results suggest that mixing grass silage and whole crop silage up to a whole crop silage proportion of 0.4 in forage DM may improve silage DM intake, and subsequently maintain or even increase milk yield. This can be explained by the good intake characteristics of whole crop silage and by the synergistic effect of combining grass and whole crop silages. The response in milk production may depend on the relative difference in the digestibility of grass and whole crop silage. 


\title{
AGRICULTURAL AND FOOD SCIENCE
}

\author{
Jaakkola, S. et al. Whole-crop silage for dairy cows
}

Protein supplementation, different levels of concentrate and energy source of concentrate induced mainly similar intake and milk yield responses with diets based on grass silage alone or on mixtures of grass and whole crop silages. However, the synergistic effect of mixing grass and whole crop silages was realized better in milk yield in the experiments where the protein concentration of concentrate was high (200 $\left.\mathrm{g} \mathrm{kg}^{-1} \mathrm{DM}\right)$. Low N concentration of whole crop silage allows a use of a relatively high protein supplementation without excessively impaired efficiency of $\mathrm{N}$ utilization.

Acknowledgements. The authors wish to acknowledge the technical assistance and cooperation of the staff in Lintupaju Experimental Farm, and other staff of Animal Nutrition and Jokioinen Estates, MTT Agrifood Research Finland. We thank Rehuraisio Oy, Kemira Oyj, Valio Oy, Junkkari Oy, NHK-keskus and Konefarmi Oy for co-operation.

\section{References}

Abdalla, A. L., Sutton, J. D., Phipps, R. H. \& Humphries, D. J. 1999. Digestion in the rumen of lactating dairy cows given mixtures of urea-treated whole-crop wheat and grass silage. Animal Science 69: 203-212.

Ahvenjärvi, S., Joki-Tokola, E., Vanhatalo, A., Jaakkola, S. \& Huhtanen, P. 2006. Effects of replacing grass silage with barley silage in dairy cow diets. Journal of Dairy Science 89: 1678-1687.

Alaspää, M. 1986. Effect of treatment with urea or a urea + ureaphosphate mixture on the nutritive value of whole crop silage. Annales Agriculturae Fenniae, Seria Animalia domestica 74: 99-103.

Bach Knudsen, K. E., Åman, P. \& Eggum, P.O. 1987. Nutritive value of Danish grown barley varietes. I. Carbohydrates and other major constituents. Journal of Cereal Science 6: 173-186.

Bergen, W. G., Byrem, T. M. \& Grant, A. L. 1991. Ensiling characteristics of whole-crop small grains harvested at milk and dough stages. Journal of Animal Science 69: 1766-1774.

Chow, L. O., Baron, V. S., Corbett, R. \& Oba, M. 2008. Effects of planting date on fiber digestibility of whole-crop barley and productivity of lactating dairy cows. Journal of Dairy Science 91: 1534-1543.

Crovetto, G. M., Galassi, G., Rapetti, L., Sandrucci, A. \& Tamburini, A. 1998. Effect of the stage of maturity on the nutritive value of whole crop wheat silage. Livestock Production Science 55: 21-32.

Davis, A. W. \& Hall, W. B. 1969. Cyclic change-over designs. Biometrika 56: 283-293.

Deschard, G., Tetlow, R. M. \& Mason, V. C. 1987. Treatment of whole-crop cereals with alkali. 3. Voluntary intake and digestibility studies in sheep given immature wheat ensiled with sodium hydroxide, urea or ammonia. Animal Feed Science and Technology 18: 283-293.

Edwards, R. A., Donaldson, E. \& MacGregor, A. W. 1968. Ensilage of whole crop barley. 1. Effects of variety and stage of growth. Journal of the Science of Food and Agriculture 19: 656-660.

Eun, J., Beauchemin, K. A., Hong, S. \& Yang, W. Z. 2004. Effects of mechanical processing on the nutritive value of barley silage for lactating dairy cows. Journal of Dairy Science 87: 4170-4177.

Friedel, K. 1990. Die Schätzung des energetischen Futterwertes von Grobfutter mit Hilfe einer Cellulasemethode (in German). Wissenschaftliche Zeitung Universitet Rostock, N-Reihe 39: 78-86.

Givens, D. I., Moss, A. R. \& Adamson, A. H. 1993. The digestion and energy value of whole crop wheat treated with urea. Animal Feed Science and Technology 43: 51-64.

Hameleers, A. 1998. The effects of the inclusion of either maize silage, fermented whole crop wheat or urea-treated whole crop wheat in a diet based on a high-quality grass silage on the performance of dairy cows. Grass and Forage Science 53: 157-163.

Hill, J. \& Leaver, J. D. 1999a. Effect of stage of growth at harvest and level of urea application on chemical changes during storage of whole-crop wheat. Animal Feed Science and Technology 77: 281-301.

Hill, J. \& Leaver, J. D. 1999b. Energy and protein supplementation of dairy cows offered urea treated whole-crop wheat as the sole feed. Animal Feed Science and Technology 82:177-193.

Hoover, W. H. 1986. Chemical factors involved in ruminal fibre digestion. Journal of Dairy Science 69: 2755-2766.

Huhtanen, P. \& Heikkilä, T. 1996. Effects of physical treatment of barley and rapeseed meal in dairy cows given grass silage-based diets. Agricultural and Food Science in Finland 5: 399-412.

Huhtanen, P. 1998. Supply of nutrients and productive responses in dairy cows given diets based on restrictively fermented silage. Agricultural and Food Science in Finland 7: 219-250.

Huhtanen, P., Nousiainen, J. \& Rinne, M. 2006. Recent developments in forage evaluation with special reference to practical applications. Agricultural and Food Science 15: 293-323.

Huhtanen, P., Rinne, M. \& Nousiainen, J. 2007. Evaluation of the factors affecting silage intake of dairy cows: a revision of the relative silage dry-matter intake index. $A n$ imal 1: 758-770.

Jaakkola, S., Kaunisto, V. \& Huhtanen, P. 2006a. Volatile fatty acid proportions and microbial protein synthesis in the rumen of cattle receiving grass silage ensiled with different rates of formic acid. Grass and Forage Science 61: 282-292.

Jaakkola, S., Rinne, M., Heikkilä, T., Toivonen, V. \& Huhtanen, P. 2006b. Effects of restriction of silage fermentation with formic acid on milk production. Agricultural and Food Science 15: 200-218.

Jackson, M. A., Readman, R. J., Huntington, J. A. \& Sinclair, L. A. 2004. The effects of processing at harvest and cutting height of urea-treated whole-crop wheat on 


\section{AGRICULTURAL AND FOOD SCIENCE}

Vol. 18 (2009): 234-256.

performance and digestibility in dairy cows. Animal Science 78: 467-476

Khorasani, G. R., Okine, E. K. \& Kennelly, J. J. 1996. Forage source alters nutrient supply to the intestine without influencing milk yield. Journal of Dairy Science 79: 862-872.

Kristensen, V. F. 1992. The production and feeding of wholecrop cereals and legumes in Denmark. In: Whole-crop cereals. p. 21-37. ed. Stark, B. A. and Wilkinson, J. M. Chalcombe Publications.

Leaver, J. D. \& Hill, J. 1995. The performance of dairy cows offered ensiled whole-crop wheat, urea-treated wholecrop wheat or sodium hydroxide-treated wheat grain and wheat straw in a mixture with grass silage. Animal Science 61: 481-489.

MacGregor, A. W. \& Edwards, R. A. 1968. Ensiling of wholecrop barley II. Composition of barley and barley silage at different stages of growth. Journal of the Science of Food and Agriculture 19: 661-666.

McCleary, B.V., Solah, V. \& Gibson, T. S. 1994. Quantitative measurement of total starch in cereal flours and products. Journal of Cereal Science 20: 51-58.

McDonald, P., Henderson, A. R. \& Heron, S. J. E. 1991. The biochemistry of silage. Second edition. Chalcombe Publication, $340 \mathrm{p}$.

MAFF 1975. Ministry of Agriculture, Fisheries and Food. Energy allowances and feeding systems for ruminants. Technical Bulletin 33. Her Majesty's Stationery Office, London, 79 p.

MAFF 1984. Ministry of Agriculture, Fisheries and Food. Energy allowances and feeding systems for ruminants. Reference Book 433. Her Majesty's Stationary Office, London, $85 \mathrm{p}$.

MTT 2006. Rehutaulukot ja ruokintasuositukset (Feed tables and feeding recommendations). Jokioinen: Agrifood Research Finland. Available at: http://www.agronet.fi/rehutaulukot/. URN:NBN:fi-fe20041449.

Nadeau, E. 2007. Effects of plant species, stage of maturity and additive on the feeding value of whole-crop cereal silage. Journal of the Science of Food and Agriculture 87: 789-801.

Nousiainen, J., Rinne, M., Hellämäki, M. \& Huhtanen, P. 2003. Prediction of the digestibility of the primary growth of grass silages harvested at different stages of maturity from chemical composition and pepsin-cellulase solubility. Animal Feed Science and Technology 103: 97-111.

Owens, D., McGee, M., Boland, T. \& O'Kiely, P. 2008. Rumen fermentation, microbial protein synthesis, and nutrient flow to the omasum in cattle offered corn silage, grass silage, or whole-crop wheat. Journal of Animal Science 87: 658-668.

Phipps, R. H., Sutton, J. D. \& Jones, B. A. 1995. Forage mixtures for dairy cows: the effect on dry matter intake and milk production of incorporating either fermented or urea-treated whole-crop wheat, brewers' grains, fodder beet or maize silage into diets based on grass silage. Animal Science 61: 491-496.

Rinne, M., Jaakkola, S., Kaustell, K., Heikkilä, T. \& Huhtanen, P. 1999. Silages harvested at different stages of grass growth $v$. concentrate foods as energy and protein sources in milk production. Animal Science 69: 251-263.

SAS 1989. Statistical Analysis Systems Institute. 1989.
SAS/STAT® User's Guide, version 6, fourth edition. SAS Institute Inc., Cary, North Carolina.

Sinclair, L. A., Wilkinson, R. G. \& Ferguson, D. M. R. 2003. Effects of crop maturity and cutting height on the nutritive value of fermented whole crop wheat and milk production in dairy cows. Livestock Production Science 81: 257-269.

Sjaunja, L. O., Baevre, L., Junkkarinen, L., Pedersen, J. \& Setälä, J. 1990. A Nordic proposal for an energy corrected milk (ECM) formula. Proceedings of the 27 th biennal session of the International Committee for Animal Recording (ICAR), Paris, France, p. 156. EAAP publication No. 50.

Soita, H. W., Christensen, D. A. McKinnon, J. J. \& Mustafa, A. F. 2002. Effects of barley silage of different theoretical cut length on digestion kinetics in ruminants. Canadian Journal of Animal Science 82: 207-213.

Soita, H. W., Christensen, D. A. \& McKinnon, J. J. 2003. Effects of barley silage particle size and concentrate level on rumen kinetic parameters and fermentation pattern in steers. Canadian Journal of Animal Science 82: $207-213$.

Stark, B. A. \& Wilkinson, J. M. 1995. Whole-crop cereals. Chalcombe Publications. $175 \mathrm{p}$

Südekum, K.-H. \& Arndt, E. 1998. Getreide-Ganzpflanzensilagen: Inhaltsstoffe und Futterwert für Wiederkäuer (in German). Übersichten für Tierernährung 26: 87-122.

Sutton, J. D., Abdalla, A. L., Phipps, R. H., Cammell, S. B. \& Humphries, D. J. 1997. The effect of the replacement of grass silage by increasing proportions of ureatreated whole-crop wheat on food intake and apparent digestibility and milk production by dairy cows. Animal Science 65: 343-351.

Sutton, J. D., Phipps, R. H., Deaville, E. R., Jones, A. K. \& Humphries, D. J. 2002. Whole-crop wheat for dairy cows: Effects of crop maturity, a silage inoculant and an enzyme added before feeding on food intake and digestibility and milk production. Animal Science 74: 307-318.

Tetlow, M. R. 1992. A decade of research into whole-crop cereals at Hurley. In: Whole-crop cereals. p. 1-19. ed. Stark, B. A. \& Wilkinson, J. M., Chalcombe Publications.

Vanhatalo, A., Jaakkola, S., Rauramaa, A., Nousiainen, J. \& Tommila, A. 1999. Additives in ensiling whole crop barley. The XIIth International Silage Conference, Uppsala, Sweden, p. 121-122.

van Keulen, J. \& Young, B. A. 1977. Acid insoluble ash as a natural marker for digestibility studies. Journal of Animal Science 44: 282-287

Walsh, K., O'Kiely, P., Taweel, H. Z., McGee, M., Moloney, A. P. \& Boland, T. M. 2009. Intake, digestibility and rumen characteristics in cattle offered whole-crop wheat or barley silages of contrasting grain to straw ratios. Animal Feed Science and Technology 148: 192-213.

Wallsten, J. \& Martinsson, K. 2009. Effects of maturity stage and feeding strategy of whole crop barley silage on intake, digestibility and milk production in dairy cows. Livestock Science 121: 155-161.

Wallsten. J., Nadeau, E., Bertilsson, B. \& Martinsson, K. 2009. Voluntary intake and diet selection by dairy heifers fed ensiled whole-crop barley and oats harvested at different stages of maturity. Livestock Science 122: 94-98. 


\title{
AGRICULTURAL AND FOOD SCIENCE
}

Jaakkola, S. et al. Whole-crop silage for dairy cows

\section{SELOSTUS}

\section{Muurahaishapolla säilötty ohra- ja vehnäkokoviljasäilörehu lypsylehmän ruokinnassa: viljan kehitysasteen, kokoviljasäilörehun osuuden ja väkirehutäydennyksen määrän ja laadun vaikutus}

\author{
Seija Jaakkola, Eeva Saarisalo ja Terttu Heikkilä \\ Helsingin yliopisto ja MTT
}

Kolmessa lypsylehmien ruokintatutkimuksessa tutkittiin nurmisäilörehun osittaista korvaamista kokoviljasäilörehulla. Kokeissa käytettiin taikinatuleentuneena korjattua ohraa tai kevätvehnää, joiden kuiva-ainepitoisuus vaihteli välillä $300-450 \mathrm{~g} \mathrm{~kg}^{-1}$. Kaikki rehut säilöttiin laakasiiloon tai torniin ja säilönnässä käytettiin muurahaishappopohjaista säilöntäainetta $\left(5 \mathrm{lt}^{-1}\right)$. Ruokintakokeissa tutkittiin säilörehujen lisäksi myös rehujen energia- ja valkuaistäydennystä. Kokeessa I nurmisäilörehua korvattiin ohrasäilörehulla eri ruokinnoissa 0 , 200, 400 tai $600 \mathrm{~g} \mathrm{~kg}^{-1}$ kuiva-ainetta (KA). Säilörehun lisäksi lehmät saivat päivittäin $10 \mathrm{~kg}$ väkirehua, joka sisälsi rypsirouhetta 0 tai $2 \mathrm{~kg}$. Kokeessa II ohra korjattiin kolmena kertana $(\mathrm{O} 1, \mathrm{O} 2, \mathrm{O} 3)$ viikon välein. Jokaista ohrasäilörehua syötettiin seoksena nurmisäilörehun kanssa ja ohrasäilörehun osuus karkearehusta oli $400 \mathrm{~g}$ $\mathrm{kg}^{-1} \mathrm{KA}$. Lisäksi O2-kokoviljasäilörehua ja nurmisäilörehua syötettiin ainoana karkearehuna. Väkirehuina (11 $\mathrm{kg} / \mathrm{pv}$ ) verrattiin viljapohjaista kotiseosta ja kaupallista täysrehua, jonka tärkkelyspitoisuus oli pienempi kuin kotiseoksen. Kokeessa III puolestaan sekä ohra että kevätvehnä korjattiin kahden viikon välein. Kokoviljasäilörehu syötettiin nurmisäilörehun kanssa seoksena, jossa kokoviljasäilörehun osuus oli $400 \mathrm{~g} \mathrm{~kg}^{-1} \mathrm{KA}$. Ruokintoja täydennettiin kahdella eri väkirehumäärällä (vanhemmat lehmät 9 tai $14 \mathrm{~kg} / \mathrm{pv}$, ensikot 7,2 ja 11,2 kg/pv).

Sekä nurmisälörehujen että kokoviljasäilörehujen käymislaatu oli hyvä. Vuosien väliset erot sääolosuhteissa sekä viljan kehitysaste vaikuttivat tähkän osuuteen kasvissa ja sen kautta sokerin, tärkkelyksen ja kuidun (NDF) pitoisuuksiin kokoviljasäilörehuissa. Kokoviljasäilörehun lisääminen ruokintaan huononsi rehuannoksen sulavuutta. Vaikutuksen voimakkuus riippui nurmirehun sulavuudesta ja kokoviljarehun osuudesta seoksessa. Kokovilja- ja nurmiseoksen syöttäminen ei kuitenkaan vähentänyt rehun syönnin kokonaismäärää. Tästä johtuen maitotuotos ei muuttunut tai tuotos jopa hieman lisääntyi kokeissa II ja III verrattuna nurmisäilörehuruokintaan. Sen sijaan kokeessa I maitotuotos väheni, kun kokoviljasäilörehun osuus karkearehusta oli 400 tai $600 \mathrm{~g} \mathrm{~kg}^{-1} \mathrm{KA}$. Tutkitut ohran kehitysasteet vaikuttivat hyvin vähän maitotuotokseen, mutta kevätvehnän korjuun siirto taikinatuleentumisvaiheen loppupuolelle lisäsi tuotosta. Väkirehuvaihtoehtojen välillä ei ollut juuri eroa nurmisäilörehun ja nurmi-kokoviljaseoksen täydentäjinä. Nurmisäilörehun ja kokoviljasäilörehun seoksen positiivinen vaikutus maitotuotokseen oli suurin kokeissa II ja III, joissa väkirehun raakavalkuaispitoisuus oli melko suuri (200 $\left.\mathrm{g} \mathrm{kg}^{-1} \mathrm{KA}\right)$. Kokoviljasäilörehun pieni raakavalkuaispitoisuus mahdollistaa suhteellisen runsaan valkuaistäydennyksen ilman, että typen hyväksikäyttö heikkenee oleellisesti. 